\title{
Associations between ambient ozone, hydrocarbons, and childhood wheezy episodes: a prospective observational study in south east London
}

\author{
Roger Buchdahl, Charlotte Daman Willems, Margaret Vander, Abdel Babiker
}

\begin{abstract}
Objectives-To explore the hypothesis that hydrocarbon species and other air pollutants which accumulate at low and high concentrations of ozone are more directly associated with childhood wheezy episodes than ozone.
\end{abstract}

Methods-Prospective observational study over 1 year set in the Lewisham district of south east London. The daily attendance rate of children with acute wheeze at the accident and emergency department of Lewisham Hospital was related to local measurements of ozone, hydrocarbon species, nitrogen dioxide $\left(\mathrm{NO}_{2}\right)$, sulphur dioxide $\left(\mathrm{SO}_{2}\right)$ and small particulate matter with diameter $<10 \mu \mathrm{m}\left(\mathbf{P} \mathbf{M}_{10}\right)$.

Results-An inverse relation was found between the air pollutants and ozone. After seasonal and meteorological adjustment a non-linear $U$ shaped trend was found between incidence of wheeze and ozone. The trend was significant in children $<2$ years of age but not in older children. In the younger age group, after adjustment for season, temperature, wind speed, and respiratory infection, the incidence relative to that at the mean daily ozone concentration of $32.7 \mu \mathrm{g} / \mathrm{m}^{3}$, was estimated to increase by $65 \%(95 \%$ confidence interval $(95 \% \mathrm{CI}) 22 \%$ to $122 \%$ ) at an ozone concentration of $5 \mu \mathrm{g} / \mathrm{m}^{3}(1.5 \mathrm{SDs}$ below the mean) and by $63 \%(95 \% \mathrm{CI}-6 \%$ to $184 \%)$ at $80 \mu \mathrm{g} / \mathrm{m}^{3}(2.5 \mathrm{SDs}$ above the mean). For several hydrocarbons there were significant positive linear relations found, again in children $<2$ years of age but not older children. For benzene, the incidence increased by $8 \%(95 \%$ CI 2 to $13 \%$ ) per SD (SD $2.8 \mu \mathrm{g} / \mathrm{m}^{3}$ ) increase in benzene concentration. A same day association between incidence and ozone was found to be the most significant but for other pollutants a lag of 2 days gave the most significant associations. No significant association was found for the nonhydrocarbon pollutants including $\mathrm{SO}_{2}$, $\mathrm{NO}_{2}$, and $\mathbf{P} \mathbf{M}_{10}$.

Conclusions-A U shaped relation was found between ozone and the incidence of wheezy episodes in young children. Certain hydrocarbon pollutants accumulate in the atmosphere when ozone concentrations are low, and are associated with childhood wheezy episodes. However, the $U$ shaped association of ozone on inci- dence cannot be explained by these other pollutants. The finding supports an earlier finding that incidences of wheeze are at a minimum when ozone concentrations are 30-40 $\mu \mathrm{g} / \mathrm{m}^{3}$.

(Occup Environ Med 2000;57:86-93)

Keywords: air pollution; ozone; hydrocarbons; childhood wheezing

In 1998 the Committee on the Medical Effects of Air Pollutants (COMEAP) published a report on the health effects of air pollution outlining the effects of ozone peaks during the summer months on hospital admissions and mortality. ${ }^{1}$ The report discussed the uncertainty of covariation of other pollutants and also the paucity of data directly applicable to conditions in the United Kingdom through a lack of field and epidemiological studies. One recent study suggested that the additional hospital admission for respiratory disease attributable to ozone was very small at concentrations $<100 \mu \mathrm{g} / \mathrm{m}^{3}$. ${ }^{2}$ A study in west London measuring rates of accident and emergency attendance for childhood wheezy episodes found a $U$ shaped relation between attendance and ozone concentrations. The effect was independent of season and weather factors, the implication being that ozone was either acting as a surrogate for other causative triggers at low concentrations, or that at a critical atmospheric concentration ozone in some way might be acting in a protective capacity. ${ }^{3}$ Air pollutant episodes have been divided into three main generic groups ${ }^{4}$ : type 1 summer photodependent smog when small particulate matter with diameter $<10 \mu \mathrm{m}\left(\mathrm{PM}_{10}\right)$, nitrogen dioxide $\left(\mathrm{NO}_{2}\right)$, and some hydrocarbons accumulate at high ozone concentrations; type 2 (vehicle); and type 3 (mixed source) smogs when the same pollutants plus sulphur dioxide $\left(\mathrm{SO}_{2}\right)$ may accumulate but at low concentrations of ozone and low light conditions. Our study sought to examine the relation between ozone and other pollutants throughout the year. It sought to test the reproducibility of the $U$ shaped relation found in the earlier study ${ }^{3}$ and finally to explore the hypothesis that those hydrocarbons accumulating at low and high concentrations of ozone of might have clinical relevance in the aetiology of acute childhood wheezing. ${ }^{5}$ 
Table 1 Pollutants and their principle sources

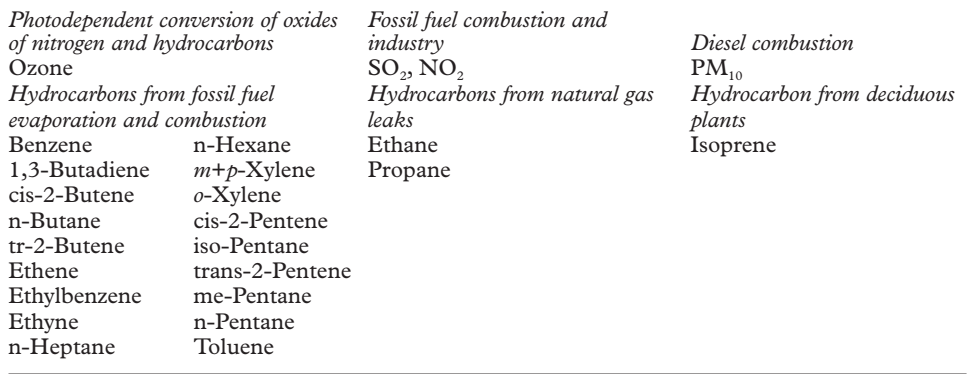

$\mathrm{SO}_{2}=$ sulphur dioxide; $\mathrm{NO}_{2}=$ nitrogen dioxide; $\mathrm{PM}_{10}=$ small particulates with diameter $<10 \mu \mathrm{m}$.

\section{Methods}

SUBJECTS

Between 1 December 1995 and 30 November 1996 the number of children (aged $\leqslant 16$ years) attending the Lewisham Children's Hospital accident and emergency department each day with symptoms of acute wheeze was noted. Diagnoses as recorded by the examining doctor included asthma (atopic or non-atopic), bronchiolitis, brochospasm, and wheezy bronchitis. Other diagnoses such as upper respiratory infection, cough (non-specific), or pneumonia were not included. Data were recorded with the department's attendance database. The hospital has a local patient catchment area of about 250000 patients, of whom 50000 are under the age of 16 years. A record of the daily attendance of children at the department for all non-respiratory conditions provided the control population over the same period. A control group was included as climatic and air pollutant factors (including ozone) have been shown before to effect the pattern of non- respiratory visits to accident and emergency centres. ${ }^{6}$

AIR POLLUTANT AND METEOROLOGICAL DATA

Data on air pollution were obtained from The Department of Environment's National Air Quality Information Archive (data are available in the public domain and may be accessed through the National Environmental Technology Centre internet site http://www.aeat.co.uk/ netcen/airqual/data/auto.html). Hydrocarbon species were measured with automatic on line gas chromatography by a monitor located in Eltham. All 21 of the hydrocarbons measured at the site were included in the analysis. The hydrocarbons are derived from three main sources: fossil fuel evaporation and combustion-for example, petrol or diesel, natural gas leaks, and biogenic leaks (deciduous plants in the summer and autumn, table 1). ${ }^{7-9} \mathrm{~A}$ monitor located in Bexley measured ozone, $\mathrm{SO}_{2}, \mathrm{NO}_{2}$, and $\mathrm{PM}_{10}$ (small particulates with diameter $<10 \mu \mathrm{m})$. Pollutant concentrations were expressed as 24 hour means. Also daily ozone concentrations were expressed as maximum 1 hour average and the maximum 8 hour moving average (as recommended by the Department of Health). ${ }^{10}$ Both monitors measure suburban background concentrations of air pollutants and are located to the east of the hospital within 10 miles of the catchment area of the patient population. The Meteorological Office in Bracknell provided meteorological data-from measurements at the London Weather Centre, 6 miles to the north west of the hospital. Data included mean 24 hourly temperature and wind speed.

Table 24 Hour means (SDs) for air pollutants $\left(\mu \mathrm{g} / \mathrm{m}^{3}\right.$ except $\left.P M_{10}-p p b\right)$ and daily incidence of wheezy cases and controls

\begin{tabular}{|c|c|c|c|c|c|}
\hline & Spring & Summer & Autumn & Winter & All seasons \\
\hline \multicolumn{6}{|l|}{ Pollutant } \\
\hline Ozone & $46.3(16.7)^{\star \star \star}$ & $40.6(13.3)^{\star \star \star}$ & $22.0 \quad(15.4)$ & $22.3 \quad(15.9)$ & 32.7 (18.8) \\
\hline $\mathrm{SO}_{2}$ & $13.6(11.5)^{\star \star \star}$ & $14.7(14.3)^{\star \star \star}$ & $14.7 \quad(13.4)$ & $27.7 \quad(24.3)$ & $17.7 \quad(17.5)$ \\
\hline $\mathrm{NO}_{2}$ & $41.7(19.1)^{\star}$ & $37.8(14.4)^{\star \star \star}$ & $46.0(17.6)^{\star \star \star}$ & $48.7 \quad(17.4)$ & $43.6 \quad(17.6)$ \\
\hline $\mathrm{PM}_{10}$ & $23.5(11.6)^{\star \star \star}$ & $23.8(10.8)^{\star \star \star}$ & $19.7(10.7)^{\star \star \star}$ & $32.2(20.1)$ & 24.9 (14.6) \\
\hline Benzene & $2.54(1.24)^{\star \star}$ & $2.59(1.33)$ & $5.08(4.22)$ & $4.08(2.56)$ & $3.57(2.83)$ \\
\hline 1,3-Butadiene & $0.86(0.55)^{\star \star}$ & $1.02(0.74)$ & $1.82(2.01)$ & $1.33(1.34)$ & $1.26(1.34)$ \\
\hline cis-2-Butene & $0.19(0.09)$ & $0.22(0.10)$ & $0.47(0.46)^{\star \star}$ & $0.31(0.30)$ & $0.30(0.30)$ \\
\hline n-Butane & $6.12(3.71)$ & $6.39(3.57)$ & $13.00(11.65)^{\star \star}$ & $9.14(7.53)$ & $8.65(7.85)$ \\
\hline tr-2-Butene & $0.40(0.13)$ & $0.43(0.16)$ & $0.77(0.64)^{\star \star}$ & $0.54(0.42)$ & $0.53(0.42)$ \\
\hline Ethene & $5.27(2.66)^{\star \star \star}$ & $5.49(2.82)^{\star \star \star}$ & $11.68(10.00)$ & $10.80(7.58)$ & $8.29(7.16)$ \\
\hline Ethylbenzene & $1.36(0.67)^{\star}$ & $1.44(0.76)$ & $3.18(2.85)^{\star \star}$ & $2.17(1.63)$ & $2.06(1.89)$ \\
\hline Ethyne & $3.48(1.92)^{\star \star}$ & $3.18(1.66)^{\star \star \star}$ & $7.08(6.24)$ & $5.63(2.68)$ & $4.82(3.94)$ \\
\hline n-Heptane & $0.30(0.15)^{\star \star \star}$ & $0.30(0.15)^{\star \star \star}$ & $0.63(0.55)$ & $0.52(0.37)$ & $0.44(0.37)$ \\
\hline n-Hexane & $0.69(0.47)^{\star \star}$ & $0.76(0.44)^{\star \star}$ & $1.23(1.04)$ & $1.11(0.85)$ & $0.94(0.77)$ \\
\hline $\mathrm{m}+\mathrm{p}$-Xylene & $3.36(1.74)^{\star}$ & $3.62(2.02)$ & $8.07(7.31)^{\star \star \star}$ & $5.29(4.22)$ & $5.14(4.86)$ \\
\hline o-Xylene & $1.38(0.74)^{\star}$ & $1.31(0.64)^{\star}$ & $3.20(2.99)^{\star \star}$ & $2.23(1.71)$ & $2.06(1.95)$ \\
\hline cis-2-Pentene & $0.14(0.07)$ & $0.17(0.99)$ & $0.38(0.20)^{\star \star \star}$ & $0.22(0.20)$ & $0.22(0.23)$ \\
\hline iso-Pentane & $6.59(3.94)$ & $7.67(4.27)$ & $11.93(10.86)^{\star \star \star}$ & $7.56(7.30)$ & $8.44(7.41)$ \\
\hline trans-2-Pentene & $0.23(0.13)$ & $0.32(0.19)$ & $0.69(0.66)^{\star \star \star}$ & $0.40(0.38)$ & $0.41(0.43)$ \\
\hline me-Pentane & $2.70(1.47)^{\star}$ & $2.93(1.58)$ & $5.47(5.17)^{\star}$ & $4.12(3.56)$ & $3.80(3.48)$ \\
\hline n-Pentane & $1.32(0.77)^{\star}$ & $1.58(0.91)$ & $2.61(2.19)^{\star \star}$ & $1.79(1.35)$ & $1.82(1.49)$ \\
\hline Toluene & $6.37(3.27)^{\star}$ & $6.92(3.57)$ & $14.00(12.63)^{\star \star}$ & $9.76(7.99)$ & $9.26(8.39)$ \\
\hline Ethane & $5.15(2.24)^{\star \star \star}$ & $3.83(1.76)^{\star \star \star}$ & $6.69(5.14)$ & $7.88(3.54)$ & $5.88(3.74)$ \\
\hline Propane & $2.36(1.31)^{\star \star \star}$ & $1.95(0.99)^{\star \star \star}$ & $4.02(3.13)$ & $4.58(2.27)$ & $3.22(2.36)$ \\
\hline Isoprene & $0.26(0.20)$ & $0.60(0.31)^{\star \star \star}$ & $0.48(0.41)^{\star \star}$ & $0.30(0.26)$ & $0.41(0.33)$ \\
\hline Average $\mathrm{HC}$ & $2.45(1.19)^{\star}$ & $2.40(1.13)^{\star}$ & $5.05(4.25)^{\star}$ & $3.75(2.60)$ & $3.47(2.86)$ \\
\hline \multicolumn{6}{|l|}{ Incidence: } \\
\hline All cases & $3.2(1.9)^{\star \star}$ & $3.2(2.8)^{\star \star}$ & $5.1 \quad(2.7)$ & $4.5 \quad(2.5)$ & $4.0 \quad(2.6)$ \\
\hline Cases $<2$ years & $2.0(1.0)^{\star \star \star}$ & $0.8(1.1)^{\star \star \star}$ & $2.3(1.8)$ & $2.0 \quad(1.7)$ & $1.6(1.6)$ \\
\hline Cases $>2$ years & $2.1 \quad(1.5)$ & $2.3 \quad(2.2)$ & $2.8 \quad(1.8)$ & $2.5 \quad(1.9)$ & $2.4 \quad(1.9)$ \\
\hline All controls & $63.5(9.8)^{\star \star \star}$ & $59.5 \quad(10.1)$ & $56.8 \quad(9.9)$ & $56.5 \quad(9.2)$ & $59.1 \quad(10.1)$ \\
\hline
\end{tabular}

${ }^{\star} \mathrm{p}<0.05 ;{ }^{\star \star} \mathrm{p}<0.01 ;^{\star \star \star} \mathrm{p}<0.001 v$ winter season.

$\mathrm{SO}_{2}=$ sulphur dioxide; $\mathrm{NO}_{2}=$ nitrogen dioxide; $\mathrm{PM}_{10}=$ small particulates with diameter $<10 \mu \mathrm{m}$; Average $\mathrm{HC}=$ average of all 21 hydrocarbons. 

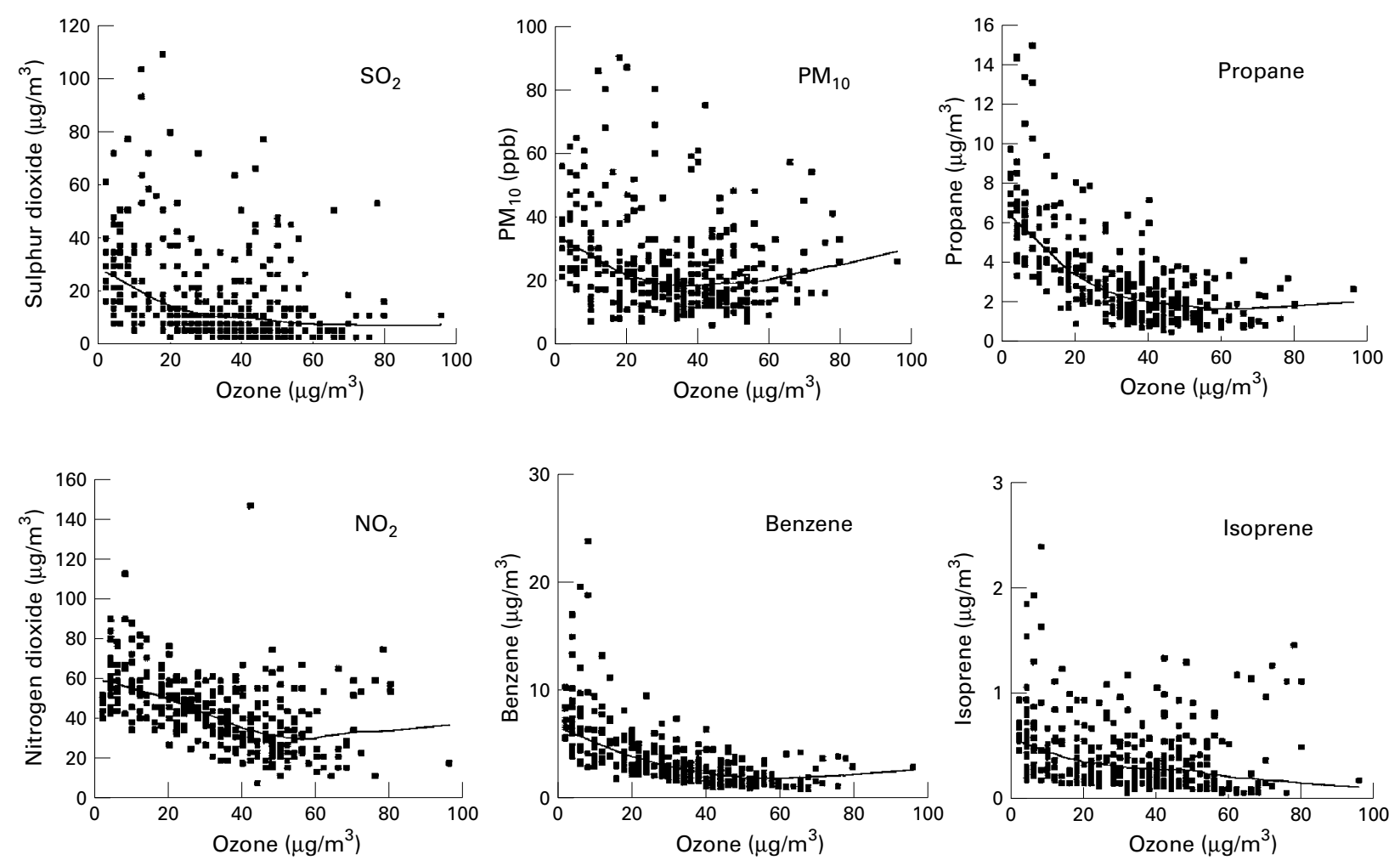

Figure 1 Scatterplots (with Lowess locally weighted smoothing average lines) exploring the relations between $\mathrm{SO}_{2}, \mathrm{NO}_{2}, \mathrm{PM}_{10}$, propane, benzene, isoprene, and ozone.

RESPIRATORY INFECTION

With respiratory infection an important factor in the aetiology of childhood wheezing additional adjustment was made for infection in the models. Over the study period, the daily rate of reported identification of respiratory pathogens was used (the number of pathogens identified on the day the microbiological specimen was obtained from the patient). The following pathogens were included: adenovirus, coronavirus, Coxiella burnetti, influenza A, influenza B, Mycoplasma pneumoniae, parainfluenza (1 and 2 ), respiratory syncytial virus, and rhinovirus. The daily total of these pathogens was used in the analysis. The data were obtained from over 18000 separate notifications to the Communi-

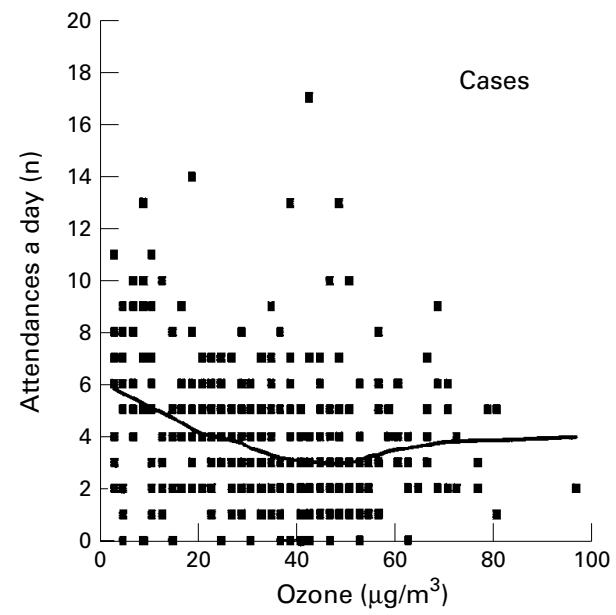

cable Diseases Surveillance Centre from laboratories in England and Wales.

\section{STATISTICAL ANALYSIS}

Data were analysed with STATA and SPSS statistical software packages. ${ }^{11}$ Scatterplots with Lowess ${ }^{12}$ locally weighted smoothing averages initially examined associations between daily mean ozone, hydrocarbons, $\mathrm{SO}_{2}, \mathrm{NO}_{2}$, and $\mathrm{PM}_{10}$ with daily incidence of wheeze. Poisson regression models were then used, with daily incidence log linear in the predictor variables. The effect of each pollutant on daily incidence was explored with stepwise adjustment of season, temperature, wind speed, and infection. Also the daily average of all 21

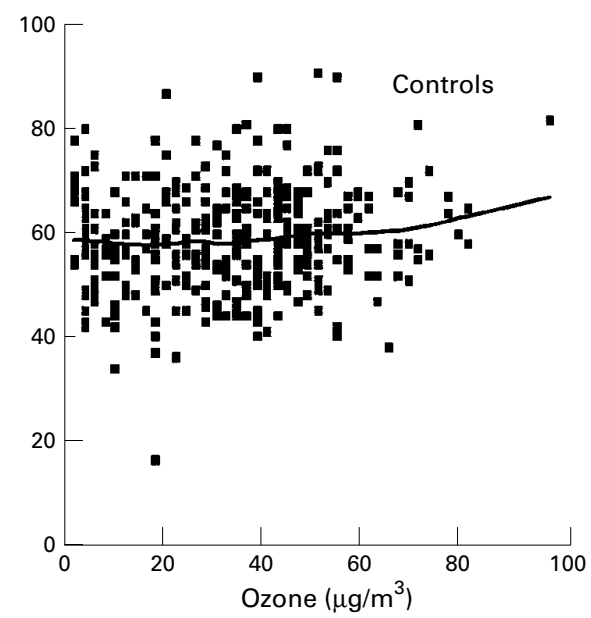

Figure 2 Scatterplots (with Lowess locally weighted smoothing average lines) exploring the relations between daily wheezy episodes for all children and ozone. 
Table 3 The effect of lagging incidence

\begin{tabular}{|c|c|c|c|c|c|c|}
\hline Pollutant & $\begin{array}{l}\text { Lag } n \\
\text { (days) }\end{array}$ & $\triangle S D$ & Total cases & Cases $<2 y$ & Cases $>2 y$ & Total controls \\
\hline \multirow[t]{5}{*}{ Ozone } & 0 & -1.5 & $1.22(0.96$ to 1.55$)$ & $1.65(1.22$ to 2.22$)$ & 0.97 (0.69 to 1.36$)$ & $1.04(0.97$ to 1.12$)$ \\
\hline & 1 & -1.5 & $1.16(0.96$ to 1.40$)$ & $1.36(1.07$ to 1.74$)$ & $1.02(0.78$ to 0.88$)$ & 1.03 (0.98 to 1.08$)$ \\
\hline & 2 & -1.5 & $1.16(0.99$ to 1.37$)$ & $1.16(0.91$ to 1.48$)$ & $1.18(0.90$ to 1.54$)$ & $1.04(0.99$ to 1.10$)$ \\
\hline & 3 & -1.5 & $1.06(0.88$ to 1.27$)$ & $1.30(1.02$ to 1.65$)$ & $0.92(0.70$ to 1.20$)$ & $1.02(0.96$ to 1.09$)$ \\
\hline & 4 & -1.5 & $1.00(0.79$ to 1.26$)$ & $1.13(0.82$ to 1.55$)$ & $0.92(0.65$ to 1.28$)$ & $1.06(0.98$ to 1.12$)$ \\
\hline \multirow[t]{5}{*}{ Ozone } & 0 & +2.5 & $1.42(0.99$ to 2.03$)$ & $1.63(0.94$ to 2.84$)$ & $1.30(0.87$ to 1.94$)$ & $1.03(0.93$ to 1.14$)$ \\
\hline & 1 & +2.5 & $1.16(0.83$ to 1.62$)$ & $1.29(0.71$ to 2.36$)$ & $1.08(0.72$ to 1.62$)$ & $1.01(0.91$ to 1.11$)$ \\
\hline & 2 & +2.5 & $0.83(0.55$ to 1.25$)$ & $0.90(0.49$ to 1.66$)$ & $0.81(0.51$ to 1.28$)$ & 0.96 (0.87 to 1.07$)$ \\
\hline & 3 & +2.5 & $0.96(0.69$ to 1.33$)$ & $1.17(0.73$ to 1.88$)$ & $0.85(0.54$ to 1.35$)$ & $0.97(0.88$ to 1.07$)$ \\
\hline & 4 & +2.5 & $0.96(0.70$ to 1.32$)$ & $0.92(0.59$ to 1.45$)$ & $0.98(0.65$ to 1.48$)$ & $1.04(0.95$ to 1.14$)$ \\
\hline \multirow[t]{5}{*}{$\mathrm{SO}_{2}$} & 0 & +1 & $1.04(0.97$ to 1.11$)$ & $1.03(0.94$ to 1.13$)$ & $1.04(0.69$ to 1.13$)$ & $1.04(1.02$ to 1.05$)$ \\
\hline & 1 & +1 & $1.05(0.99$ to 1.11$)$ & $1.04(0.96$ to 1.13$)$ & $1.05(0.98$ to 1.13$)$ & $1.02(1.01$ to 1.04$)$ \\
\hline & 2 & +1 & 1.07 (1.00 to 1.15$)$ & $1.04(0.97$ to 1.12$)$ & $1.09(1.00$ to 1.19$)$ & $1.02(1.00$ to 1.03$)$ \\
\hline & 3 & +1 & $1.05(0.98$ to 1.11$)$ & $1.06(0.97$ to 1.16$)$ & $1.04(0.96$ to 1.11$)$ & $1.02(1.00$ to 1.04$)$ \\
\hline & 4 & +1 & $1.01(0.95$ to 1.08$)$ & $1.01(0.93$ to 1.09$)$ & $1.02(0.94$ to 1.11$)$ & $1.02(1.00$ to 1.04$)$ \\
\hline \multirow[t]{5}{*}{$\mathrm{NO}_{2}$} & 0 & +1 & $0.97(0.88$ to 1.06$)$ & $1.03(0.92$ to 1.16$)$ & $0.93(0.82$ to 1.06$)$ & $1.00(0.98$ to 1.02$)$ \\
\hline & 1 & +1 & $1.02(0.96$ to 1.08$)$ & $1.07(0.98$ to 1.17$)$ & $0.99(0.91$ to 1.07$)$ & $1.00(0.99$ to 1.02$)$ \\
\hline & 2 & +1 & 1.05 (1.00 to 1.10$)$ & 1.07 (0.98 to 1.17$)$ & $1.04(0.98$ to 1.11$)$ & $1.02(1.00$ to 1.03$)$ \\
\hline & 3 & +1 & $1.00(0.94$ to 1.06$)$ & $1.00(0.91$ to 1.09$)$ & $0.99(0.92$ to 1.08$)$ & $1.01(1.00$ to 1.03$)$ \\
\hline & 4 & +1 & $0.98(0.91$ to 1.06$)$ & $1.05(0.94$ to 1.17$)$ & $0.94(0.86$ to 1.02$)$ & $1.02(1.00$ to 1.03$)$ \\
\hline \multirow[t]{5}{*}{$\mathrm{PM}_{10}$} & 0 & +1 & $1.04(0.97$ to 1.12$)$ & $1.05(0.95$ to 1.15$)$ & $1.04(0.95$ to 1.14$)$ & 1.02 (1.00 to 1.04$)$ \\
\hline & 1 & +1 & $1.03(0.97$ to 1.11$)$ & $1.03(0.95$ to 1.12$)$ & $1.04(0.95$ to 1.14$)$ & $1.01(1.00$ to 1.03$)$ \\
\hline & 2 & +1 & $1.06(0.99$ to 1.14$)$ & $1.00(0.92$ to 1.09$)$ & $1.10(1.00$ to 1.21$)$ & 1.01 (1.00 to 1.03$)$ \\
\hline & 3 & +1 & $1.05(0.98$ to 1.11$)$ & $1.03(0.94$ to 1.12$)$ & $1.06(0.99$ to 1.14$)$ & $1.01(0.99$ to 1.03$)$ \\
\hline & 4 & +1 & $1.01(0.95$ to 1.07$)$ & $1.00(0.91$ to 1.10$)$ & $1.01(0.94$ to 1.10$)$ & $1.01(0.99$ to 1.03$)$ \\
\hline \multirow[t]{5}{*}{ Average $\mathrm{HC}$} & 0 & +1 & 1.00 (0.93 to 1.08$)$ & $1.04(0.96$ to 1.13$)$ & $0.97(0.85$ to 1.10$)$ & 1.00 (0.98 to 1.03$)$ \\
\hline & 1 & +1 & $1.05(1.00$ to 1.10$)$ & $1.08(1.02$ to 1.15$)$ & $1.02(0.93$ to 1.12$)$ & $1.00(0.98$ to 1.02$)$ \\
\hline & 2 & +1 & $1.06(1.03$ to 1.10$)$ & $1.08(1.02$ to 1.14$)$ & $1.05(0.99$ to 1.11$)$ & $1.00(0.98$ to 1.02$)$ \\
\hline & 3 & +1 & $1.03(0.99$ to 1.08$)$ & $1.07(1.00$ to 1.15$)$ & $1.00(0.94$ to 1.06$)$ & $1.01(1.00$ to 1.03$)$ \\
\hline & 4 & +1 & $1.04(0.98$ to 1.10$)$ & $1.11(1.03$ to 1.18$)$ & $0.98(0.92$ to 1.05$)$ & $1.01(1.00$ to 1.03$)$ \\
\hline
\end{tabular}

$0=$ Pollutant and incidence measured on same day; $1=$ pollutant measured 1 day before incidence etc. Incidences $(95 \% \mathrm{CIs}) / \Delta \mathrm{SD}$ of pollutant relative to incidence at mean annual concentration of pollutant. Adjustment made for season, temperature, wind speed, and infection.

Abbreviations as for table 2 .

hydrocarbons was calculated. We used the Poisson distribution because the distribution of the daily incidence was highly skewed. ${ }^{13}$ For each variable $\mathrm{v}$, a restricted natural cubic spline function ${ }^{14}$ with knots at the 10th, 50th, and 90th centiles was used in the Poisson model to formally test for non-linearity in the relation between $\mathrm{v}$ and incidence. This amounted to adding a completely specified piecewise cubic function $\mathrm{S}(\mathrm{v})$ to the variable $\mathrm{v}$ in the model (see appendix). The test for non-linearity is equivalent to testing the significance of $\mathrm{S}(\mathrm{v})$. Additional adjustment was made in the case of ozone for average hydrocarbons. Models were adjusted for potential model mis-specification and for autocorrelation between daily incidence up to 7 days earlier, with the NeweyWest estimator. ${ }^{15}$ Season was divided into a

Table 4 Incidences (95\% CI)/ASD of pollutant relative to incidence at mean annual concentration of pollutant adjusted for season, temperature, wind speed, and infection (for ozone 0.5 SDs)

\begin{tabular}{|c|c|c|c|c|c|}
\hline Pollutant & $\triangle S D$ & Total cases & Cases $<2 y$ & Cases $>2 y$ & Total controls \\
\hline \multirow[t]{6}{*}{ Ozone } & -1.5 & $1.22(0.96$ to 1.55$)$ & 1.65 (1.22 to 2.22$)$ & $0.97(0.69$ to 1.36$)$ & $1.04(0.97$ to 1.12$)$ \\
\hline & -0.5 & $1.03(0.96$ to 1.10$)$ & $1.10(1.03$ to 1.19$)$ & $0.98(0.89$ to 1.07$)$ & $1.01(0.99$ to 1.03$)$ \\
\hline & 0 & 1.00 & 1.00 & 1.00 & 1.00 \\
\hline & +0.5 & $1.03(0.97$ to 1.09$)$ & $1.01(0.94$ to 1.10$)$ & $1.04(0.97$ to 1.11$)$ & $1.00(0.99$ to 1.01$)$ \\
\hline & +1.5 & $1.20(0.98$ to 1.46$)$ & $1.27(0.93$ to 1.72$)$ & $1.16(0.92$ to 1.45$)$ & $1.02(0.96$ to 1.07$)$ \\
\hline & +2.5 & $1.42(0.99$ to 2.03$)$ & $1.63(0.94$ to 2.84$)$ & $1.30(0.87$ to 1.94$)$ & $1.03(0.93$ to 1.14$)$ \\
\hline $\mathrm{SO}_{2}$ & +1 & $1.07(1.00$ to 1.15$)$ & $1.05(0.97$ to 1.12$)$ & $1.09(1.00$ to 1.19$)$ & $1.02(1.00$ to 1.03$)$ \\
\hline $\mathrm{NO}_{2}$ & +1 & $1.05(1.00$ to 1.10$)$ & $1.07(0.98$ to 1.17$)$ & $1.04(0.98$ to 1.11$)$ & $1.02(1.00$ to 1.03$)$ \\
\hline $\mathrm{PM}_{10}$ & +1 & $1.06(0.99$ to 1.14$)$ & $1.00(0.92$ to 1.09$)$ & $1.10(1.00$ to 1.21$)$ & $1.01(1.00$ to 1.03$)$ \\
\hline Benzene & +1 & $1.06(1.03$ to 1.09$)$ & $1.08(1.02$ to 1.13$)$ & $1.05(0.99$ to 1.10$)$ & $1.01(0.99$ to 1.02$)$ \\
\hline 1,3-Butadiene & +1 & $1.06(1.02$ to 1.10$)$ & $1.06(1.00$ to 1.14$)$ & $1.05(0.98$ to 1.13$)$ & $0.99(0.98$ to 1.00$)$ \\
\hline cis-2-Butene & +1 & $1.03(1.00$ to 1.07$)$ & $1.05(1.00$ to 1.11$)$ & $1.02(0.97$ to 1.06$)$ & $1.00(0.98$ to 1.01$)$ \\
\hline n-Butane & +1 & $1.04(1.01$ to 1.08$)$ & $1.06(1.00$ to 1.12$)$ & $1.03(0.98$ to 1.08$)$ & $1.00(0.98$ to 1.02$)$ \\
\hline tr-2-Butene & +1 & $1.04(1.00$ to 1.07$)$ & $1.05(1.00$ to 1.11$)$ & $1.02(0.98$ to 1.07$)$ & $1.00(0.98$ to 1.02$)$ \\
\hline Ethene & +1 & $1.07(1.03$ to 1.11$)$ & $1.08(1.01$ to 1.15$)$ & $1.06(0.99$ to 1.12$)$ & $1.01(0.99$ to 1.03$)$ \\
\hline Ethylbenzene & +1 & $1.05(1.02$ to 1.09$)$ & $1.08(1.03$ to 1.14$)$ & $1.03(0.98$ to 1.09$)$ & $1.00(0.99$ to 1.02$)$ \\
\hline Ethyne & +1 & $1.04(1.00$ to 1.08$)$ & $1.07(1.02$ to 1.12$)$ & $1.02(0.97$ to 1.07$)$ & $1.01(0.99$ to 1.02$)$ \\
\hline n-Heptane & +1 & $1.05(1.02$ to 1.09$)$ & $1.07(1.02$ to 1.13$)$ & $1.04(0.99$ to 1.09$)$ & $1.00(0.99$ to 1.02$)$ \\
\hline n-Hexane & +1 & $1.06(1.02$ to 1.10$)$ & 1.07 (1.00 to 1.14$)$ & $1.05(0.99$ to 1.10$)$ & $1.01(0.99$ to 1.03$)$ \\
\hline $\mathrm{m}+\mathrm{p}$-Xylene & +1 & $1.05(1.02$ to 1.09$)$ & $1.08(1.03$ to 1.14$)$ & $1.03(0.98$ to 1.09$)$ & $1.01(0.98$ to 1.03$)$ \\
\hline o-Xylene & +1 & $1.06(1.02$ to 1.09$)$ & $1.08(1.03$ to 1.14$)$ & $1.03(0.98$ to 1.09$)$ & $1.00(0.99$ to 1.02$)$ \\
\hline cis-2-Pentene & +1 & $1.04(1.01$ to 1.08$)$ & $1.07(1.02$ to 1.13$)$ & $1.02(0.97$ to 1.07$)$ & $0.99(0.98$ to 1.01$)$ \\
\hline iso-Pentane & +1 & $1.04(1.01$ to 1.08$)$ & $1.06(1.00$ to 1.12$)$ & $1.03(0.98$ to 1.08$)$ & $1.00(0.99$ to 1.02$)$ \\
\hline trans-2-Pentene & +1 & 1.04 (1.01 to 1.07$)$ & 1.07 (1.01 to 1.12$)$ & $1.02(0.97$ to 1.07$)$ & $1.00(0.98$ to 1.01$)$ \\
\hline me-Pentane & +1 & $1.05(1.02$ to 1.09$)$ & $1.08(1.02$ to 1.14$)$ & $1.04(0.99$ to 1.09$)$ & $1.00(0.99$ to 1.02$)$ \\
\hline n-Pentane & +1 & 1.05 (1.01 to 1.08$)$ & 1.06 (1.01 to 1.12$)$ & $1.03(0.98$ to 1.09$)$ & $1.00(0.98$ to 1.02$)$ \\
\hline Toluene & +1 & 1.05 (1.02 to 1.09$)$ & $1.07(1.01$ to 1.13$)$ & $1.04(0.98$ to 1.10$)$ & $1.00(0.99$ to 1.02$)$ \\
\hline Ethane & +1 & $1.05(1.00$ to 1.10$)$ & $1.05(0.97$ to 1.14$)$ & $1.05(0.98$ to 1.12$)$ & $1.00(0.99$ to 1.02$)$ \\
\hline Propane & +1 & $1.05(1.00$ to 1.11$)$ & 1.07 (0.99 to 1.15$)$ & $1.04(0.97$ to 1.12$)$ & $1.01(0.99$ to 1.03$)$ \\
\hline Isoprene & +1 & $1.03(0.98$ to 1.08$)$ & $1.07(1.01$ to 1.15$)$ & $1.00(0.93$ to 1.07$)$ & $1.02(1.00$ to 1.04$)$ \\
\hline Average HC & +1 & $1.06(1.03$ to 1.10$)$ & $1.08(1.02$ to 1.14$)$ & $1.05(0.99$ to 1.11$)$ & $1.00(0.98$ to 1.02$)$ \\
\hline
\end{tabular}

Values for ozone with lag $=0$ days. Values for all other pollutants with lag=2 days. 
Table 5 Incidence (95\% CI)/ASD) of ozone relative to incidence at mean annual pollutant concentration adjusted for season, temperature, wind speed, average hydrocarbons, and infection (lag=0 days)

\begin{tabular}{llllll}
\hline Pollutant & ASD & Total cases & Cases $<2 y$ & Cases $>2 y$ & Total controls \\
\hline Ozone & -1.5 & $1.21(0.90$ to 1.63$)$ & $1.65(1.14$ to 2.40$)$ & $0.96(0.64$ to 1.45$)$ & $1.05(0.96$ to 1.13$)$ \\
& -0.5 & $1.03(0.95$ to 1.11$)$ & $1.11(1.01$ to 1.21$)$ & $0.97(0.87$ to 1.08$)$ & $1.00(0.99$ to 1.03$)$ \\
& 0 & 1.00 & 1.00 & 1.00 & 1.00 \\
& +0.5 & $1.04(0.97$ to 1.11$)$ & $1.01(0.93$ to 1.10$)$ & $1.06(0.97$ to 1.15$)$ & $1.00(0.99$ to 1.02$)$ \\
& +1.5 & $1.27(0.98$ to 1.66$)$ & $1.24(0.87$ to 1.77$)$ & $1.25(0.95$ to 1.64$)$ & $1.02(0.96$ to 1.08$)$ \\
& +2.5 & $1.52(1.00$ to 2.30$)$ & $1.57(0.82$ to 3.02$)$ & $1.48(0.90$ to 2.88$)$ & $1.04(0.92$ to 1.16$)$ \\
\hline
\end{tabular}

four level factor (Spring 22 March to 21 June; Summer 22 June to 21 September; Autumn 22 September to 21 December; and Winter 22 December to $21 \mathrm{March})$. The possibility of a lag effect up to 4 days was explored. The analyses were performed on cases and control for children of all ages and then divided into children under and over 2 years of age.

Similarly, scatterplots were used to explore associations between daily mean ozone and concentrations of pollutants. Regression models were constructed examining these relations with adjustment for season, temperature, and wind speed.

\section{Results}

Table 2 summarises the data on pollutants and incidence by season. Information for each hydrocarbon is given as well as the mean hydrocarbon summary. A total of 1461 wheezy attendances (572 in children $<2$ years) and 21631 non-respiratory attendances (6062 in children $<2$ years) were recorded during the year. There were significantly more wheezy attendances during the autumn and winter seasons than in the spring and summer. Levels of most of the pollutants were significantly greater in the autumn or winter than in the spring and summer. The exceptions were ozone and isoprene. Compared with winter, ozone concentrations were significantly higher in the spring and summer and isoprene concentrations were significantly higher in the summer and autumn months.

RELATION BETWEEN OZONE AND HYDROCARBONS, $\mathrm{NO}_{2}, \mathrm{SO}_{2}, \mathrm{AND} \mathrm{PM}_{10}$

Examples of the relations between 24 hour mean concentrations of air pollutants and ozone over the year are shown in figure 1. For hydrocarbons one example from each of the main source groups is shown: benzene (petrol and diesel), propane (natural gas), and isoprene (deciduous plants). The scatterplots and Lowess smoothing average lines show that all pollutants tended to accumulate at the lowest concentrations of ozone. Except for 1,3butadiene the global test and test of nonlinearity of the regression of each hydrocarbon, $\mathrm{NO}_{2}, \mathrm{SO}_{2}$, and $\mathrm{PM}_{10}$ on ozone remained significant even after adjustment for season, temperature, and wind speed. The relations remained significant irrespective of how ozone was expressed, as daily means, maximum 1 hour, or 8 hour averages.

\section{WHEEZY INCIDENCE AND OZONE}

Figure 2 gives the scatterplots with Lowess smoothing average lines relating daily incidence of wheeze to 24 hour daily mean ozone concentrations. A U shape trend was found with incidence at about 6 cases a day at the

Table 6 Models showing the effect of stepwise adjustment, incidences (95\% CIs)/ $\triangle S D$ of pollutant relative to incidence at mean pollutant concentration (for ozone lag $=0$ days; for all other pollutants lag $=2$ days)

\begin{tabular}{|c|c|c|c|c|c|}
\hline Pollutant & $\triangle S D$ & Total cases & Cases $<2 y$ & Cases $>2 y$ & Total controls \\
\hline Ozone unadjusted & -1.5 & $1.64(1.32$ to 2.04$)$ & $2.69(2.09$ to 3.47$)$ & $1.14(0.86$ to 1.52$)$ & $1.00(0.94$ to 1.06$)$ \\
\hline+ Seas & -1.5 & 1.39 (1.18 to 1.64$)$ & 2.01 (1.61 to 2.52$)$ & $1.04(0.82$ to 1.31$)$ & $1.04(0.98$ to 1.11$)$ \\
\hline +Seas+temp & -1.5 & $1.24(1.01$ to 1.53$)$ & $1.85(1.42$ to 2.42$)$ & $0.91(0.68$ to 1.21$)$ & $1.06(0.99$ to 1.13$)$ \\
\hline +Seas+temp+ws & -1.5 & $1.26(1.00$ to 1.58$)$ & $1.84(1.37$ to 2.48$)$ & $0.93(0.66$ to 1.31$)$ & $1.03(0.97$ to 1.10$)$ \\
\hline Seas+temp+ws+inf & -1.5 & $1.22(0.96$ to 1.55$)$ & $1.65(1.22$ to 2.22$)$ & $0.97(0.69$ to 1.36$)$ & $1.04(0.97$ to 1.12$)$ \\
\hline Ozone unadjusted & +2.5 & $1.06(0.81$ to 1.30$)$ & $1.19(0.73$ to 1.93$)$ & $0.96(1.37$ to 0.83$)$ & $1.10(1.00$ to 1.20$)$ \\
\hline+ Seas & +2.5 & $1.26(0.91$ to 1.74$)$ & $1.53(0.89$ to 2.62$)$ & $1.11(0.77$ to 1.59$)$ & $1.04(0.95$ to 1.14$)$ \\
\hline +Seas+temp & +2.5 & $1.45(1.02$ to 2.04$)$ & $1.68(0.97$ to 2.92$)$ & $1.31(0.88$ to 2.18$)$ & $1.01(0.92$ to 1.12$)$ \\
\hline +Seas+temp+ws & +2.5 & $1.43(1.00$ to 2.04$)$ & $1.69(0.97$ to 2.94$)$ & $1.28(0.86$ to 1.91$)$ & $1.03(0.93$ to 1.14$)$ \\
\hline+ Seas+temp+ws+inf & +2.5 & $1.42(0.99$ to 2.03$)$ & $1.63(0.94$ to 2.84$)$ & $1.30(0.87$ to 1.94$)$ & $1.03(0.93$ to 1.14$)$ \\
\hline $\mathrm{SO}_{2}$ unadjusted & +1 & $1.11(1.04$ to 1.19$)$ & $1.13(1.04$ to 1.24$)$ & $1.10(1.01$ to 1.19$)$ & $1.00(0.98$ to 1.02$)$ \\
\hline+ Seas & +1 & $1.10(1.02$ to 1.18$)$ & $1.09(0.99$ to 1.19$)$ & $1.11(1.01$ to 1.21$)$ & $1.01(0.99$ to 1.03$)$ \\
\hline+ Seas+temp & +1 & $1.07(1.00$ to 1.14$)$ & $1.05(0.97$ to 1.14$)$ & $1.08(0.99$ to 1.18$)$ & $1.02(1.00$ to 1.04$)$ \\
\hline+ Seas+temp+ws & +1 & $1.07(1.00$ to 1.15$)$ & $1.05(0.97$ to 1.13$)$ & $1.09(1.00$ to 1.18$)$ & $1.02(1.00$ to 1.03$)$ \\
\hline+ Seas+temp+ws+inf & +1 & $1.07(1.00$ to 1.15$)$ & $1.04(0.97$ to 1.12$)$ & $1.09(1.00$ to 1.19$)$ & $1.02(1.00$ to 1.03$)$ \\
\hline $\mathrm{NO}_{2}$ unadjusted & +1 & 1.10 (1.03 to 1.18$)$ & $1.17(1.05$ to 1.29$)$ & $1.06(0.99$ to 1.13$)$ & $1.01(0.99$ to 1.03$)$ \\
\hline+ Seas & +1 & $1.07(1.01$ to 1.13$)$ & $1.09(0.99$ to 1.20$)$ & $1.05(0.99$ to 1.12$)$ & $1.02(1.00$ to 1.03$)$ \\
\hline +Seas+temp & +1 & $1.05(1.00$ to 1.10$)$ & $1.07(0.98$ to 1.17$)$ & $1.04(0.98$ to 1.11$)$ & $1.02(1.00$ to 1.03$)$ \\
\hline +Seas+temp+ws & +1 & $1.05(1.00$ to 1.10$)$ & $1.06(0.97$ to 1.16$)$ & $1.04(0.98$ to 1.11$)$ & $1.02(1.00$ to 1.03$)$ \\
\hline+ Seas + temp $+w s+\inf$ & +1 & $1.05(1.00$ tp 1.10$)$ & $1.07(0.98$ to 1.17$)$ & $1.04(0.98$ to 1.11$)$ & $1.02(1.00$ to 1.03$)$ \\
\hline $\mathrm{PM}_{10}$ unadjusted & +1 & 1.07 (1.00 to 1.14$)$ & $1.03(0.96$ to 1.11$)$ & $1.09(0.99$ to 1.19$)$ & $1.01(0.99$ to 1.03$)$ \\
\hline+ Seas & +1 & $1.07(0.99$ to 1.15$)$ & $1.01(0.92$ to 1.11$)$ & $1.11(1.00$ to 1.22$)$ & $1.01(0.99$ to 1.03$)$ \\
\hline+ Seas+temp & +1 & $1.06(0.98$ to 1.13$)$ & $1.00(0.91$ to 1.09$)$ & $1.10(1.00$ to 1.21$)$ & $1.01(1.00$ to 1.03$)$ \\
\hline +Seas+temp+ws & +1 & $1.06(0.98$ to 1.13$)$ & $1.00(0.92$ to 1.08$)$ & $1.10(1.00$ to 1.21$)$ & $1.01(1.00$ to 1.03$)$ \\
\hline+ Seas+temp+ws+inf & +1 & $1.06(0.99$ to 1.14$)$ & $1.00(0.92$ to 1.09$)$ & $1.10(1.00$ to 1.21$)$ & $1.01(1.00$ to 1.03$)$ \\
\hline Average $\mathrm{HC}$ unadjusted & +1 & 1.14 (1.09 to 1.18$)$ & $1.20(1.13$ to 1.28$)$ & $1.09(1.04$ to 1.14$)$ & $0.99(0.97$ to 1.01$)$ \\
\hline+ Seas & +1 & $1.08(1.04$ to 1.12$)$ & $1.10(1.05$ to 1.17$)$ & $1.06(1.00$ to 1.12$)$ & $1.00(0.98$ to 1.02$)$ \\
\hline +Seas+temp & +1 & 1.06 (1.03 to 1.10$)$ & 1.09 (1.03 to 1.15$)$ & $1.04(0.99$ to 1.10$)$ & $1.00(0.99$ to 1.02$)$ \\
\hline+ Seas+temp+ws & +1 & $1.06(1.03$ to 1.10$)$ & $1.08(1.02$ to 1.14$)$ & $1.05(0.99$ to 1.11$)$ & 1.00 (0.98 to 1.02$)$ \\
\hline+ Seas + temp $+w s+\inf$ & +1 & $1.06(1.03$ to 1.10$)$ & $1.08(1.02$ to 1.14$)$ & $1.05(0.99$ to 1.11$)$ & $1.00(0.98$ to 1.02$)$ \\
\hline
\end{tabular}



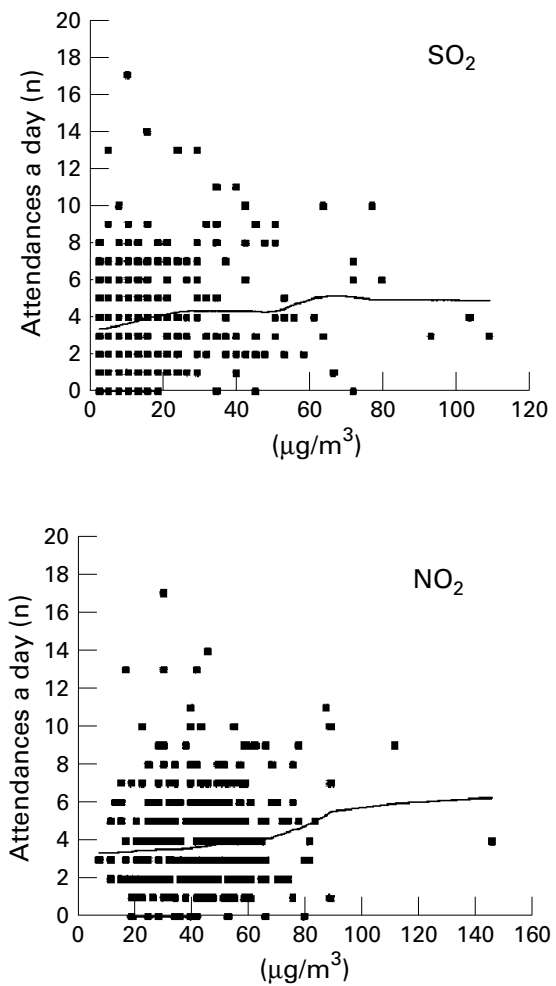
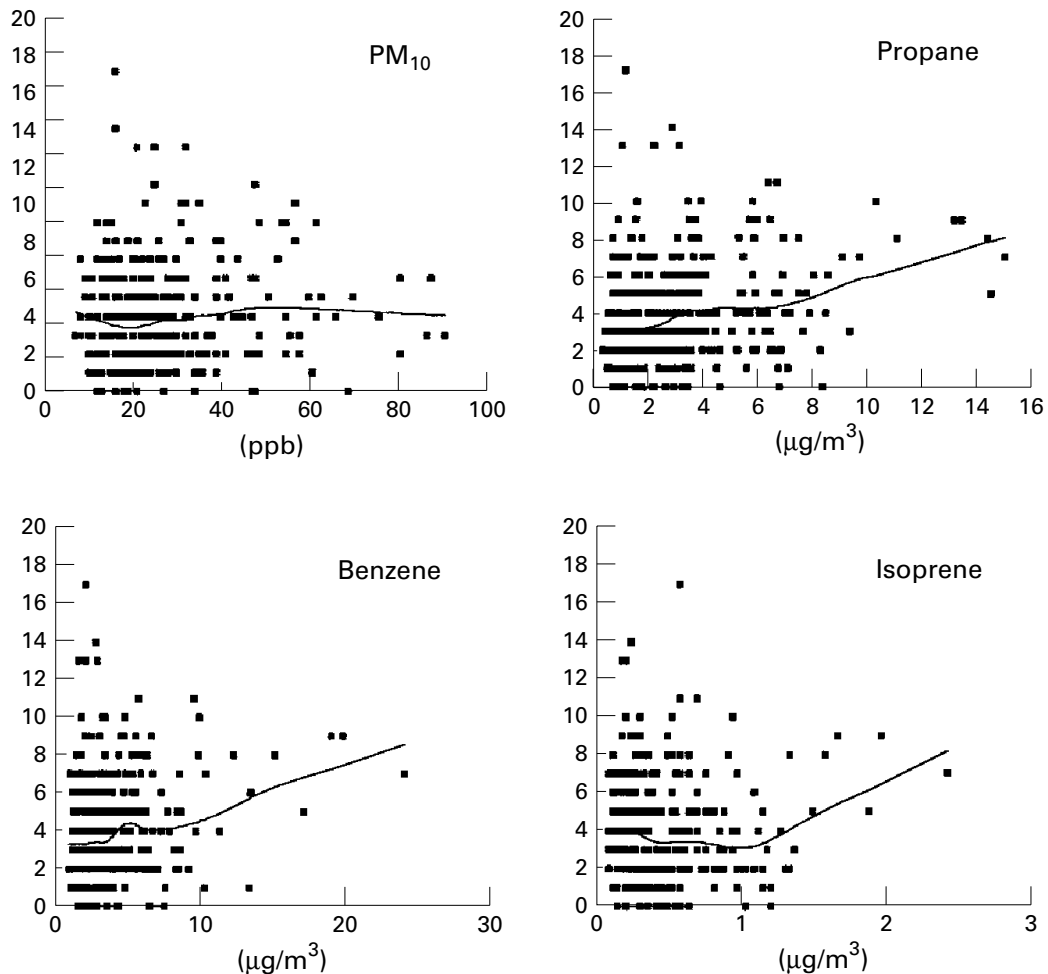

Figure 3 Scatterplots (with Lowess locally weighted smoothing average lines) exploring the relations between daily episodes of wheeze for all children and $\mathrm{SO}_{2}, \mathrm{NO}_{2}, \mathrm{PM}_{10}$, propane, benzene, and isoprene.

lowest concentrations of ozone, falling to three cases a day in the $30-40 \mu \mathrm{g} / \mathrm{m}^{3}$ range, and rising to four cases at the highest concentrations of ozone. This pattern was not found in the control population. The association of ozone was found to be greatest on the same day (lag $=0$ when pollutant and incidence were measured on same day, table 3). After adjustment for season, temperature, wind speed, and respiratory infection Poisson regression modelling (table 4) showed a significant non-linear $U$ shaped relation (global test $\chi^{2}=6.61, \mathrm{df}=2$, $\mathrm{p}<0.05$; test for non-linearity $\chi^{2}=6.48, \mathrm{df}=1$, $\mathrm{p}<0.05)$. Ozone concentrations were expressed as SDs ranging from $-1.5 \mathrm{SDs}\left(5.0 \mu \mathrm{g} / \mathrm{m}^{3}\right)$ to +2.5 SDs $\left(80.0 \mu \mathrm{g} / \mathrm{m}^{3}\right)$. The $\mathrm{U}$ shaped association could be explained largely by the effect on the population $<2$ years old (global test $\chi^{2}=11.93, \mathrm{df}=2, \mathrm{p}<0.01$; test for nonlinearity $\left.\chi^{2}=10.13, \mathrm{df}=1, \mathrm{p}<0.01\right)$. In this population even after additional adjustment for average hydrocarbons the non-linear U shaped model remained significant with significant negative associations between ozone and incidence at low concentrations of ozone (global test $\chi^{2}=7.44, \mathrm{df}=2, \mathrm{p}<0.05$; test for nonlinearity $\chi^{2}=6.21, \mathrm{df}=1, \mathrm{p}<0.05$, table 5). No significant associations were found in children over the age of 2 years. The stepwise effect of adjusting for season, temperature, wind speed, and respiratory infection on incidence is tabulated in table 6 . The non-linear relation remained highly significant irrespective of how ozone was expressed, as daily means, maximum 1 hour, or 8 hour averages. Models relating the daily attendance rate of non-respiratory controls adjusted in the same manner showed no significant association between ozone and rate of attendance of controls.

RELATION BETWEEN WHEEZY EPISODES AND HYDROCARBONS, $\mathrm{NO}_{2}, \mathrm{SO}_{2}$, AND $\mathrm{PM}_{10}$

Figure 3 gives the scatterplots with Lowess smoothing average lines relating daily incidence of wheeze to 24 hour daily mean benzene, propane, isoprene, $\mathrm{NO}_{2}, \mathrm{SO}_{2}$, and $\mathrm{PM}_{10}$. The relations were found to fit log linear Poisson regression models (table 4 ). The associations were strongest with a 2 day lag. After adjustment for season, temperature, wind speed, and respiratory infection, for average hydrocarbons the mean incidence for the total population of children was found to increase by $6 \% / \mathrm{SD}$ increase. In children $<2$ years, but not older children, several of the associations with individual hydrocarbon species were significant. For $\mathrm{NO}_{2}, \mathrm{SO}_{2}$, and $\mathrm{PM}_{10}$, trends were not significant after adjustment. Models relating the daily attendance rate of non-respiratory controls adjusted in the same manner showed no significant association between these pollutants and attendance rate except in the case of $\mathrm{SO}_{2}$ which had associations with wheeze on the same day $(\mathrm{lag}=0)$ and the day after $(\mathrm{lag}=1)$. The effects of lag and stepwise adjustment are shown in tables 3 and 6 respectively.

\section{Discussion}

The finding of a $U$ shaped relation between the incidence of wheezy episodes and daily ozone concentrations supports the findings of the previous study in west London. ${ }^{3}$ Both that report and the present findings differ from the results of other studies examining associations between ozone and attendance rates at acci- 
dent and emergency departments or studies in the field that examined associations between ozone concentrations and lung function. ${ }^{6}{ }^{16-18}$ Some studies have neglected to measure ozone outside the spring and summer seasons. Others use normal rather than Poisson regressions. Poisson regressions are more appropriate when examining skewed count data. At least two recent studies, with similar statistical approaches, have found negative associations between childhood respiratory illness and ozone concentrations. ${ }^{120}$ One of these examined the effect of both air pollution and pollens on admissions across all seasons. For children a strong negative association between childhood admissions and ozone was found in the cool season, a positive association in the warm season. The associations could not be explained by the confounding influence of airborne pollens. ${ }^{19}$ The second study with general practitioner consultation rates for asthma also found negative associations with ozone despite adjusting for meteorological and aeroallergen factors. For children the association was found in all seasons and could not be explained by confounding with $\mathrm{SO}_{2}, \mathrm{NO}_{2}$, or $\mathrm{PM}_{10}$. The associations with ozone were noted to be most significant on the same day $(\mathrm{lag}=0)$ whereas with other pollutants more significant associations were noted with lag periods of $1-2$ days. ${ }^{20}$

In the present study there were insufficient data to examine formally the relations for each of the four seasons separately; but by combining the ozone and incidence data from the present study with data from the earlier west London study ${ }^{3}$ it was possible to construct a model fitting separate linear relations for different seasons. When the model was compared with a model fitting non-linear effects as well as the separate linear parts a significant difference $(p=0.01)$ between the two models was found suggesting that the non-linear $U$ shaped relation is not explained by season.

There were a few days when ozone exceeded recommended air quality bands. ${ }^{10}$ During the year there were 21 days when concentrations exceeded the 8 hour average of $100 \mu \mathrm{g} / \mathrm{m}^{3}(50$ $\mathrm{ppb})$. On two of these days the 1 hour average exceeded $180 \mu \mathrm{g} / \mathrm{m}^{3}$ (90 $\mathrm{ppb}$ ). The mean attendance rate for these 21 days was 3.3 cases a day. Compared with the annual mean of four cases a day it is clear that most childhood wheezy episodes occur when ozone concentrations are low (table 2).

By focusing on very young children we have shown that most of the $U$ shaped relation can be explained by the effect on this population. Wheezing in young children is common. One well reported population study has suggested that up to $50 \%$ of all children under the age of 6 years may wheeze at some time in their early years. ${ }^{21}$ It is likely that the pathophysiological and immunological mechanisms operating in young children differ from those in older atopic people. ${ }^{22}$ Relevant aetiological factors include viral infection ${ }^{23}$ and exposure to cigarette smoke. ${ }^{24}$ The present study shows that respiratory infection had little effect on the relations between incidence and pollutants (table 6). It is possible, however, that the effect of infection may have been underestimated because national rather than local data were used, which could have missed local epidemics thus introducing the potential of residual confounding. Similarly a simple four level seasonal adjustment may have missed the influence of specific seasonal factors such as school holidays.

The hypothesis that other air pollutants, and in particular hydrocarbons, are more relevant at the lowest concentrations of ozone is borne out through these findings. Concentrations of several species of hydrocarbons were positively associated with wheezy episodes. It is conceivable that one or more of these may be biologically injurious to the airway either as irritants or sensitisers. But the finding that no one individual hydrocarbon stood out might suggest that these compounds are surrogate markers of one or more toxic compounds not measured in this study. Peroxyacetyl nitrate, for example, is a more reactive compound than the hydrocarbons measured in this study (RL Maynard, personal communication). It is derived from photo-oxidation of ethane and other hydrocarbons and may reach a high concentration during type 1 summer photodependent smogs. ${ }^{25}$ However, the atmospheric chemistry of the compound is complex. Concentrations can be high during low light or low temperature type 2 or type 3 smog conditions. In the context of asthma there is little published work examining the effect of peroxyacetyl nitrate or hydrocarbon species on animal or human models. The influence of hydrocarbons in this study is not sufficient to explain the $U$ shaped relation between incidence and ozone (table 5) which would seem to suggest a protective effect of ozone at lower concentrations. It may not be necessary to postulate a biological explanation for this effect. A possible explanation is that ozone may be either oxidising hydrocarbons directly $^{25}$ or under certain meteorological conditions, ${ }^{26}$ reacting with water vapour to provide a rich source of hydroxyl radicals. ${ }^{7826}$ Hydroxylation is a key mechanism involved in the oxidation and sinking of hydrocarbons as well as other pollutants in the atmosphere. By analogy ozone initiated water purification systems used in the oil industry have been shown to be highly effective in cleaning hydrocarbon contaminated water effluent. ${ }^{27}{ }^{28}$ In the summer the hydroxylation process results in a net generation of ozone, which may, during photochemical smog conditions, cause ozone and other reactive molecules to accumulate to toxic concentrations. In winter, in the absence of sufficient sunshine, at night, or when the wind speed is low, the absence of ozone may be associated with the accumulation of high concentrations of several hydrocarbon species. Attractive as this hypothesis may be it is difficult to account for the fact that the most significant association of ozone was found on the same day as attendance, which contrasted with hydrocarbons for which the clinical association became apparent after a lag of 2 days. 
We thank Penny Whiting of the Communicable Diseases Surveillance Centre, Colindale, London, for the data on respiratory infections.

\section{Statistical appendix}

Let $\mathrm{z}$ denote the ozone $\left(\mathrm{O}_{3}\right)$ concentration measured in units of $\mathrm{SDs}(\mathrm{SD}=\sigma)$ from the mean $\mathrm{O}_{3}$ concentration of $32.7 \mu \mathrm{g} / \mathrm{m}^{3}$. Then $\mathrm{z}=\left(\mathrm{O}_{3}-32.7\right) / \sigma$. A restricted cubic spline function ${ }^{14}$ with knots at the 10 th $\left(\mathrm{P}_{10}\right), 50$ th $\left(\mathrm{P}_{50}\right.$ median), and 90th $\left(\mathbf{P}_{90}\right)$ percentiles of $z$ was used to model the relation between the daily incidence of episodes of wheeze and ozone concentration. The number of episodes during a period of 24 hours is assumed to follow a Poisson distribution with log rate given by:

$\beta_{0+} \beta_{1} z+\beta_{2} S(z)$, where:

$$
\begin{array}{lr}
S(z)=0 & \text {; if } z \leqslant P_{10} \\
=\left(z-P_{10}\right)^{3} & \text {; if } P_{10}<z \leqslant P_{50} \\
=\left(z-P_{10}\right)^{3}+\frac{\left(P_{90}-P_{10}\right)}{\left(P_{90}-P_{50}\right)}\left(z-P_{50}\right) & \text { if } P_{50}<z \leqslant P_{90} \\
=\left(P_{50}-P_{10}\right)\left(P_{10}-P_{90}\right)\left(P_{10}+P_{50}+P_{90}\right)+3 & \text {; if } z>P_{90} \\
\left(P_{50}-P_{10}\right)\left(P_{90}-P_{10}\right) z &
\end{array}
$$

With the estimates $\hat{\beta}_{0}, \hat{\beta}_{1}, \hat{\beta}_{2}$ (and their standard errors) relative to the mean $\mathrm{O}_{3}$ when $\mathrm{z}=0$, the $\log$ incidence rate ratio at level $\mathrm{z}$ is estimated by $\hat{\lambda}=\hat{\beta}_{1} z+\hat{\beta}_{2} S(z)$ with standard error SE $(\hat{\lambda})$ estimated from the covariance matrix of $\hat{\beta}_{1}$ and $\hat{\beta}_{2}$. A $95 \%$ CI for $\lambda$ is then

\section{$\hat{\lambda} \pm \operatorname{SE}(\hat{\lambda}) \sqrt{\chi_{0.05}^{2}}$}

where $\chi_{0.05}^{2}$ is the $95^{\text {th }}$ centile of the $\chi^{2}$ distribution with two degrees of freedom to yield a Scheffe type simultaneous confidence interval.

1 Committee on the Medical Effects of Air Pollutants. The quantification of the effects of air pollution on health in the United Kingdom. London: Stationery Office, 1998. (ISBN 0 113221029 .)

2 Stedman JR, Anderson HR, Atkinson RW, et al. Emergency hospital admissions for respiratory disorders attributable to summer time ozone episodes in Great Britain. Thorax 1997;52:958-63.

3 Buchdahl R, Parker A, Stebbings T, et al. Association between air pollution and acute childhood wheezy episodes: prospective observational study. BMF 1996;312: 661-5.
4 Department of Health. Advisory Group on the Medical Aspects of Air Pollution Episodes. 4th Report. Health effects oxposures to mixtures of air pollutants. London: The of exposures to mixtures of air pollutants.

5 Buchdahl R, Parker A, Stebbings T, et al. Ozone and childhood wheezy episodes: authors reply [letter]. BMF 1996;312:1607-8.

6 Bates DV, Baker-Anderson M, Sitzo R. Asthma attack periodicity: a study of hospital emergency visits in Vancouver. Environ Res 1990;51:51-70.

7 Photochemical Oxidants Review Group. Ozone in the United Kingdom 1993. 3rd Report. London: Department of the Environment, 1993. (ISBN 070581683 4.)

8 Quality of Urban Air Review Group. Urban air quality in the United Kingdom. 1st Report. London: Department of the Environment, 1993. (ISBN 09520771 1 6.)

9 Field RA. The sources and behaviour of selected urban air pollutants [PhD Thesis]. London: University of London, 1995.

10 Committee on the Medical Effects of Air Pollutants. Handbook on air pollution and health. London: Department of book on air pollution and health. London: Department
Health, Stationery Office, 1997. (ISBN 011322096 0.)

11 Stata Corporation. Stata reference manual 3.1, 6th ed. College Station, TX: Stata, 1993.

12 Cleveland WS. Robust locally weighted regression and smoothing scatter plots. Fournal of the American Statistical Association 1979;74:829-36.

13 McCullagh P, Nelder JA. Generalised linear models, $2 n d$ ed. London: Chapman and Hall, 1989.

14 Durrleman S, Simon R. Flexible regression models with cubic splines. Stat Med 1989;8:551-61.

15 Newey W, West K. A simple positive semi-definite heteroscedasticity and autocorrelation consistent covariance matrix. Econometrica 1987;55:703-8.

16 Anonymous. Health effects of outdoor pollution. Committee of the Environmental and Occupational Health Assembly of the American Thoracic Society. Am $\mathcal{F}$ Respir Crit Care Med 1996;153:3-50.

17 Cody RP, Weisel CP, Birnbaum G, et al. The effect of ozone associated with summertime photochemical smog on the associated with summertime photochemical smog on the
frequency of asthma visits to hospital emergency departments. Environ Res 1992;58:184-94.

18 Spektor DM, Thurston GD, Mao J, et al. Effects of single and multiday ozone exposures on respiratory function in active normal children. Environ Res 1991;55:107-22.

19 Anderson HR, Ponce de Leon A, Bland JM, et al. Air Pollution, pollens, and daily admissions for asthma in London 1987-92. Thorax 1998;53:842-8.

20 Hajat S, Haines A, Goubet SA, et al. Association of air pollution with daily GP consultations for asthma and other lower respiratory conditions in London. Thorax 1999;54: 597-605.

21 Martinez FD, Wright AL, Taussig LM, et al, and the Group Health Medical Associates. Asthma and wheeze in the first 6 years of life. N Engl f Med 1995;332:133-8.

22 Stein RT, Holberg CJ, Morgan WJ, et al. Peak flow variability, methacholine responsivess and atopy as markers for detecting different wheezing phenotypes in childhood. Thorax 1997;52:946-52.

23 McIntosh K, Ellis EF, Hoffman LS, et al. The association of viral and bacterial respiratory infections with exacerbations in young asthmatic children. F Paediatrics 1973;82:578-90.

24 Strachan DP, Cook DG. Parental smoking and childhood asthma: longitudinal and case-control studies. Thorax 1998;53:204-12.

25 Photochemical Oxidants Review Group. Ozone in the United Kingdom. 4th Report. London: Department of the Environment, 1997. (ISBN 187039330 9.)

26 Spellman G. Analysing air pollution meteorology. Weather 1998;53:33-42.

27 Bettle G, Tittlebaum ME. Demonstration of an ozoneinitiated, oxygen-based autooxidation wastewater treatment technology. F Environ Sci Health B 1995;30:1791805.

28 Echegaray DF, Olivieri RF. Biologically resistant contaminants, primary treatment with ozone. Water Science and nants, primary treatment with
Technology 1994;29:257-61. 